\title{
Toplum Kökenli Pnömoni Tanısında İdrar Pnömokok Antijen Testini Kullanmanın Zamanı Geldi mi?
}

\section{Is it not the Time to Use Urine Pneumococal Antigen Test for the Diagnosis of Community-Acquired Pneumonia}

\author{
M. Rıdvan DUMLU'(ID), Alper ȘENER²(iD)
}

${ }^{1}$ Acıbadem Labmed Tıbbi Laboratuvarı, Klinik Mikrobiyoloji Laboratuvarı, İstanbul, Türkiye
2 Çanakkale 18 Mart Üniversitesi Tıp Fakültesi, İnfeksiyon Hastalıkları ve Klinik Mikrobiyoloji Anabilim Dalı, Çanakkale, Türkiye

Makale atıfı: Dumlu MR, Şener A. Toplum kökenli pnömoni tanısında idrar pnömokok antijen testini kullanmanın zamanı geldi mi? FLORA 2021;26(1):88-95.

\section{ÖZ}

Giriş: Toplum kökenli pnömoni (TKP), akciğer parenkiminin infeksiyon ve enflamasyonudur. Erken tanı ve erken tedavi ile mortalite ve morbidite azalır. Toplum kökenli pnömonide en sık izole edilen mikroorganizma Streptococcus pneumoniae'dır ve klasik kültür metodları halen altın standarttır. İdrar pnömokok antijen testi, çözülebilir pnömokokkal antijen tespitinde kullanılır. Çalısmada, polikliniğimize başvuran hastalarda TKP'de nokta prevelansını tespit edilerek, bu pnömoniler içinde S. pneumoniae'nin oranı ve idrar pnömokok antijen testinin tanı koyma başarısı sorgulandı.

Materyal ve Metod: Çalışmaya 01.11.2016 ile 31.01.2017 tarihleri arasında Çanakkale Onsekiz Mart Üniversitesi Tıp Fakültesi Hastanesi Infeksiyon Hastalıkları polikliniğine başvuran ve klinik, laboratuvar ve/veya radyolojik bulgularına göre TKP tanısı konulan hastalar alındı. Kan ve balgam kültürü, idrar pnömokok antijen tetkikleri çalısıldı. Bunların yanında hastaların sosyo demografik özellikleri, yandaş hastalıkları, klinik şikayetleri, CURB-65 skorları kayıt altına alındı. Verilerin SPSS Paket Program 20.0 sürümüyle istatistiksel analiz yapıldı.

Bulgular: Toplamda kırk yedi hasta çalışmada yer aldı. Hastaların \%59.4'ü erkekti ve tüm grubun yaş ortalaması $69 \pm 2$ idi. Hastaların en sık şikayeti öksürük, dispne ve takipne olup; en sık akciğer tutulumunun bilateral multilober olduğu, \%45'inin yoğun bakım ihtiyacı olduğu, en sık komorbid hastalığın konjestif kalp yetmezliği ve kronik obstrüktif akciğer hastalığı olduğu görüldü. Bir hastada balgam kültürlerinde S. pneumoniae üredi. Bu hastada idrar antijen testide pozitiflik gösterdi. Altı hastada idrar pnömokok antijen testi pozitif saptandı. Çalısma grubunda TKP nokta prevalansı \%0.31 ve S. pneumoniae'ye bağı pnömoni oranının \%12.7 olduğu görüldü.

Sonuç: Çalısmamı; TKP'de etkenin izole edilmesinde pratikte kullanılan kan ve balgam kültürlerine ek olarak idrar pnömokok antijen testinin yardımc bir tetkik olarak kullanılmasının, etkenin yakalanma oranını artırdığını göstermiştir.

Anahtar Kelimeler: Toplum kökenli pnömoni; Streptococcus pneumonia; idrar pnömokok antijen testi 


\title{
ABSTRACT \\ Is it not the Time to Use Urine Pneumococal Antigen Test for the Diagnosis of Community-Acquired Pneumonia
}

\author{
M. Rıdvan DUMLU', Alper ȘENER²
}

\author{
${ }^{1}$ Laboratory of Clinical Microbiology, Acıbadem Labmed Medical Laboratory, İstanbul, Turkey \\ ${ }^{2}$ Department of Infectious Diseases and Clinical Microbiology, Çanakkale 18 Mart University Faculty of Medicine, Çanakkale, Turkey
}

Introduction: Community-acquired pneumonia (CAP) is an infection and inflammation of the lung parenchyma. Early diagnosis and treatment reduce mortality and morbidity. The most frequently isolated microorganism is Streptococcus pneumoniae in CAP, and conventional culture methods still continue to be the gold standard. Urine pneumococcal antigen test is used to detect soluble pneumococcal antigen. In this study, the point prevalence of CAP was determined in patients admitted to our outpatient clinic, and the rate of pneumonia and the diagnostic success of the urinary pneumococcal antigen test were questioned.

Materials and Methods: Patients who were admitted to Canakkale Onsekiz Mart University Faculty of Medicine Infectious Diseases outpatient department between 01.11.2016 and 31.01.2017 were included into the study and diagnosed as CAP according to their clinical, laboratory and radiological findings. Blood and sputum culture, urine pneumococcal antigen tests were studied. In addition, sociodemographic characteristics, comorbidities, clinical complaints, CURB-65 scores of the patients were questioned, and the data were analyzed by using SPSS Package Program 20.0 version.

Results: A total of 47 patients were included into the study. Fifty-nine point six percent of the patients were males, and the mean age of the whole group was $69 \pm 2$ years. The most common complaints of the patients were cough, dyspnea and tachypnea. The most common pulmonary involvement was bilateral multilobar involvement, $45 \%$ were hospitalized in the intensive care unit, and the most common comorbid diseases were congestive heart failure and chronic obstructive pulmonary disease. Sputum culture revealed S. pneumoniae in only one patient. Urine antigen test also showed positivity in this one. Urine pneumococcal antigen test was positive in six patients. The point prevalence of CAP in the study group was $0.31 \%$, and the rate of S. pneumoniae was $12.7 \%$.

Conclusion: Our study showed that the use of urine pneumococcal antigen test as an auxiliary test in addition to blood and sputum culture increases the identification rate of the agent.

Key Words: Community-acquired pneumonia; Streptococcus pneumonia; Urine pneumococcal antigen test

\section{GiRiș}

Toplum kökenli pnömoni (TKP), akciğer parankim infeksiyonu olup, yıllık hastane yatıșlarının, is kayıplarının, tedavi masraflarının ve ölümlerin önemli bir kısmına sebep olmaktadır ${ }^{[1,2]}$. Mortalite nedenleri arasında Amerika Birlesik Devletleri'nde altınci sırada olup ülkemizde beșinci sırada yer almaktadır ${ }^{[3,4]}$. Hem etkenin izolasyonunun uzun sürmesi hem de erken baslanilan tedavinin mortalite ve morbidite oranlarını azaltması nedeniyle, tedavinin ampirik ve erken bașlanılması gerekmektedir. Uygun ampirik tedavinin seciminde de toplumun epidemiyolojik verilerine ihtiyac duyulmaktadir ${ }^{[5,6]}$. TKP'de rol oynayan etkenler Streptococcus pneumoniae, Haemophilus influenzae, Moraxella catarrhalis, anaerobik bakteriler ve gram-negatif enterik basillerdir. En sık görülen etken $S$. pneumoniae'dır ve görülme sıklığı literatürde \%16-60 arası oranlarda bildirilmistir ${ }^{[6]}$. TKP'de tanıyı fizik muayene ve akciğer grafisi bulguları ile koymak kolay olsa da, etiyolojik tespit o kadar kolay olmamaktadır. Calısmalar TKP'li olgularda tüm uygulamalara rağmen etkenin ancak \%20-50 vakada tespit edilebildiğini göstermiștir ${ }^{[7,8]}$. Etiyolojik ajanın belirlenmesinde konvansiyonel kültür yöntemleri altın standart olmaya devam etmekle birlikte, kan kültürü için \%7-10, balgam kültürü için \%10-50 gibi düșük duyarlllkklar söz konusudur. Erken ve daha hızlı sonuc verebilecek yardımcı tanı yöntemlerine ihtiyaç vardır ${ }^{[6-9]}$. İdrar antijen testleri $S$. pneumoniae ve Legionella pneumophila'nın neden olduğu akciğer infeksiyonlarını tanıya yönelik alternatif ve tamamlayıcı tetkikler olup; ceșitli nedenlerle balgam örneği alınamayan hastalarda yol gösterici olmaktadırlar. Hızlı sonuc vermeleri, antibiyotik kullanımından etkilenmemeleri, yüksek duyarllığa sahip olmaları gibi avantajları mevcut olmakla birlikte, bakteriyemik olmayan pnömonilerde duyarlllk ve özgüllükklerinin düșük 
olması ve antibiyotik duyarlılık testlerinin yapılamayıșı, testlerin kullanımdaki olumsuz yönleridir.

İdrar pnömokok antijen testi, idrar örneklerinde çözülebilir pnömokokkal antijen tespiti için kullanılan immünokromotografik bir membran testidir. Pnömokok pnömonisi tanısında hızlı sonuç veren ve kolay uygulanabilen, duyarlılığı ve özgülliüği yüksek bir testtir. Pnömoni tanı ve tedavi rehberleri tarafından, tedaviye yanıt alınamayan, yoğun bakım ünitesinde takip edilmekte olan, balgam örneği veremeyen, pnömokoksik pnömoni için risk faktörlerine sahip hastalar için yapılması önerilen yardımcı bir tanı metodudur ${ }^{[7-11]}$. Duyarlılığ \%70-80, özgüllüğü \%80-100 arasında değișmekte olup pozitif prediktif değeri \%68, negatif prediktif değeri \%92 olarak bulunmusturtur ${ }^{[12,13]}$.

$\mathrm{Bu}$ calıșmada; hastanemize bașvuran hastalarda TKP nokta prevalansının, bu hasta grubunda pnömokok nedenli pnömoninin oranının ve tanıda idrar pnömokok antijen testinin rolünün belirlenmesi amaçlanmıștır.

\section{MATERYAL ve METOD}

Calıșmamı, 01.11.2016-31.01.2017 tarihleri arasında (Canakkale Onsekiz Mart Üniversitesi Tıp Fakültesi Araștırma ve Uygulama Hastanesi'nde) TKP nedeni ile takip edilen hastalardan calıșma kabul kriterlerini karșlayan ve dıșlama kriterlerini tașımayan gönülliu hastalarla yapılmıștır. Calıșma kabul kriterleri; 18 yas ve üzerinde olmak, hastanemize pnömoni ön tanısıyla ayaktan basvurmus veya yatırılarak takip edilmiş olmak, akciğer grafisinde pnömoni ile uyumlu konsolidasyonlar (infiltratlar) gözlenmiș olması, anamnez ve fizik muayenede akut alt solunum yolu infeksiyonu ile uyumlu; $38^{\circ} \mathrm{C}$ veya daha yüksek derecede ates, dispne ve/veya takipne, yeni gelișen veya artan öksürük, plöritik göğuis ağrısı, anormal solunum sesleri semptom ve bulgularından en az ikisinin saptanmıș olması ve son 6 ay içinde pnömoni tanısı almamıs olmak seklinde belirlenmiștir. Calıșma hakkında bilgilendirilen ve yazılı bilgilendirilmiș oluru alınmıș hastalar calıșmaya dahil edilmiștir. Herhangi bir nedenle hastaneye yatıstan en az 48 saat sonra ya da taburcu olduktan sonraki ilk 48 saatte gelișen pnömonisi olan hastalar, pnömonisi endobronșiyal lezyon (kanser), klinik ve/veya radyolojik olarak belirgin bronșektazi veya bilinen tüberküloz ile ilișkili olan ve/veya evde olup trakeostomisi olan ve/veya solunumsal ve/veya nütrisyonel destek bakımı alan hastalar, sağlık bakımı için uzun süreli bakım evinde kalmakta olan hastalar, evde ayaktan parenteral antibiyotik tedavisi benzeri infüzyon tedavisi almakta olan hastalar, evde bası yarası bakımı yapılmakta olan hastalar, son 30 gün içinde hemodiyaliz merkezine tedavi amaçl devam etmekte olan hastalar, yüksek seviye immünsupresyonu olan hastalar (kombine primer immün yetmezlik hastalıkları olan, calısmaya dahil edilmeden önceki 6 ay içerisinde kemoterapi almıș olan, çalıșmaya dahil edilmeden önceki 2 ay içerisinde solid organ transplantasyonu yapilmıș olan, HIV infeksiyonu olup, CD4 T-lenfosit sayımı 200 hücre $/ \mathrm{mm}^{3}$ 'ten düșük olan, calıșmaya dahil edilmesinden önceki 14 veya daha fazla gün boyunca $20 \mathrm{mg}$ ve daha fazla prednizon/gün eșdeğeri kortikosteroid tedavisi almıș olan, tümör nekrozu faktörü alfa blokeri veya bağıșıklığı baskılayıcı ilaç (rituksimab vb.) almakta olan hastalar ise calıșmaya dahil edilmemiștir.

Katılımcılara çalıșma hakkında bilgi verilmiş ve çalıșmaya katılmaya gönüllü olup onam formunu imzalayan katılımcılar çalıșmaya alınmıștır.

Calıșma kapsamında hastalara herhangi bir müdahalede bulunulmamıs, rutinde yapilacak olan klinik muayene, laboratuvar ve görüntüleme ișlemleri veri toplama formuna kaydedilmistir. Rutin ișlemler haricinde hastalardan spot idrar numunesi alınmıș ve calıșma merkezinde kart test ile $S$. pneumoniae antijeni taraması yapılmıștır.

Pnömokok kart testin (Binax Now $\left.{ }^{\circledR}\right)$ kullanılıș1; hastadan alınan idrar örneği içine testin emdirme aparatı konulur. Daha sonra bu aparat test band1 ile birleștirilip tampon solüsyonu eklenerek bant ile temas sağlanmaya devam ettirilir. Örnekteki S. pneumoniae antijeni ile testteki antikor reaksiyona girer ve sonrasında kontrol cizgisi ortaya çkar. Bu sekilde test tamamlandıktan sonra ortaya pembe-mor arasında bir renkte cizgi cıkar. Eğer renk olușumu hem örnekte hem kontrol cizgisinde olușursa test pozitif, renk sadece kontrol cizgisinde olușursa testin negatif olduğunu anlamina gelir. Kontrol çizgisi görülmez sadece örnek çizgisi görülürse de test geçersiz sayllır (Șekil 1). Bu test Pnömokok pnömonisi tanısında hılı ve kolay bir metot olarak kullanılmakta olup; rehberlerde, yoğun 


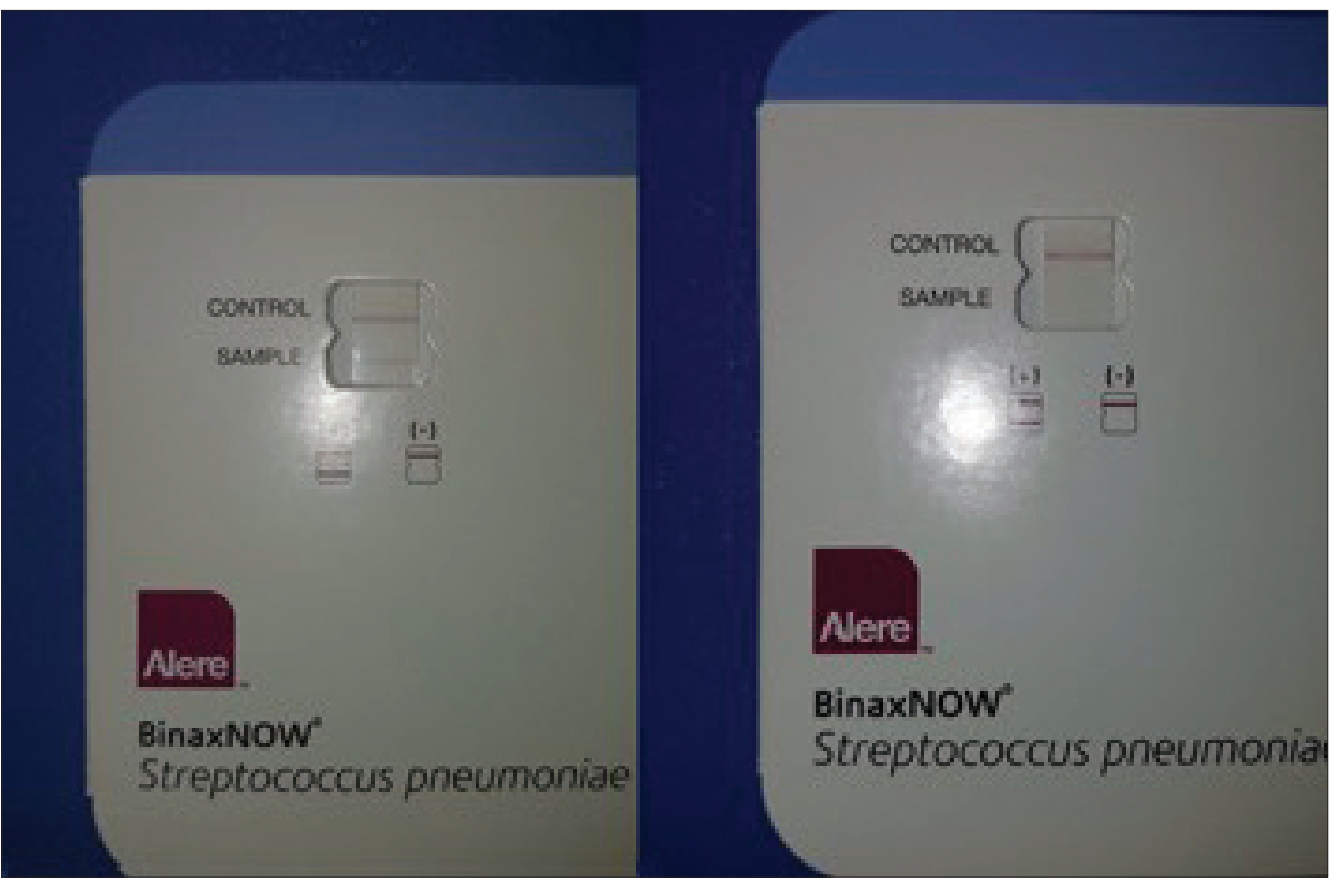

Şekil 1. İdrar pnömokok antijen testi.

bakım ünitesinde takip gerekliliği bulunan bașlangıc antibiyotik tedavisine yanıtsı, lökopeni, aspleni, plevral efüzyon ve kronik alkolizm durumları mevcut hastalarda kullanımı önerilmektedir ${ }^{[13-16]}$ Duyarllığı \%70-80, özgülllüğü \%80-100 arasında değismekte olup pozitif prediktif değeri $\% 68$, negatif prediktif değeri \%92 olarak bulunmustur ${ }^{[13,14]}$.

Hastaların sosyodemografik özellikleri, yandas hastalıkları, ilk tanı anında saptanan fizik muayene, laboratuvar ve görüntüleme bulguları, etken saptanması saptanması amacı ile bakılan kan kültürü, balgam kültürü ve idrar pnömokok antijen tetkikleri sonuçarı kaydedilmiș olup, SPSS $\mathrm{Pa}$ ket Program 20.0 sürümü kullanılarak istatistiksel analiz yapılmıștır.

\section{İstatistiksel Değerlendirme}

SPSS Paket Program 20.0 sürümü kullanılarak istatistiksel analiz yapılmıștır.

\section{BULGULAR}

Calıșmamıza alınan hastaların \%59.6'sı ( $\mathrm{n}=$ 28) erkek, \%40.4'ü (n: 19) kadındı. Hastaların yas ortalamaları ve vital bulguları incelendiğinde; yas ortalamaları $69 \pm 2$ yıl (minimum 19, maksimum 94), vital bulguları ise sistolik kan basinc1 (KB) ortalaması $108 \pm 2.7 \mathrm{mmHg}$ (minimum 80, maksimum 170), diastolik KB ortalaması $63 \pm$ $1.6 \mathrm{mmHg}$ (minimum 40, maksimum 90), ortalama KB ortalaması $78 \pm 1.8 \mathrm{mmHg}$ (minimum 53, maksimum 106), nabız ortalama $97 \pm 3.4$ atım/dk (minimum 63, maksimum 169), solunum sayısı ortalama $29.3 \pm 1.2 / \mathrm{dk}$ (minimum 12 , maksimum 42) ve ates ortalama $37.5 \pm 0.1^{\circ} \mathrm{C}$ (minimum 36.2, maksimum 38.9) tespit edilmistir (Tablo 1).

Hastaların semptomları incelendiğinde; hastaların \%96'sında ( $\mathrm{n}=45)$ öksürük, \%81'inde $(\mathrm{n}=38)$ takipne veya dispne, \%51'inde $(\mathrm{n}=24)$ göğüs ağrıs1 șikayetlerinin olduğu görülmüs olup, \%49'unda ( $\mathrm{n}=23) 38^{\circ} \mathrm{C}$ ve üstünde ates ve tamamında pnömoniye özgü anormal solunum sesleri bulguları saptanmıștır.

Hastaların \%32'sinde ( $\mathrm{n}=15)$ konjestif kalp yetersizliği $(\mathrm{KKY}), \quad \% 30$ 'unda $(\mathrm{n}=14)$ kronik obstrüktif akciğer hastalığı (KOAH), \%23'ünde $(\mathrm{n}=11)$ diabetes mellitus (DM), \%23'ünde $(\mathrm{n}=$ 11) hipertansiyon, \%23'ünde $(\mathrm{n}=11)$ kronik böbrek yetmezliği (KBY), \%23'ünde $(n=11)$ nörolojik hastallk öyküsü, \%19'unda ( $\mathrm{n}=9$ 9) koroner arter hastalığı (KAH), \%6'sında kronik karaciğer hastalığı öyküsü, \%4'ünde akciğer dıșı malignite öyküsü, \%2'sinde interstisyel akciğer hastalı̆̆1 gibi 


\begin{tabular}{|c|c|}
\hline $\begin{array}{l}\text { Demografik veriler } \\
\text { Ortalama yaş (Min-Max) } \\
\text { Cinsiyet (K/E) }\end{array}$ & $\begin{array}{l}69 \pm 2 \text { yll }(19-94) \\
19 / 28\end{array}$ \\
\hline $\begin{array}{l}\text { Fizik muayene bulgusu } \\
\text { Ortalama kan basıncı } \\
\text { Nabız } \\
\text { Solunum Sayısı } \\
\text { Ateş }\end{array}$ & $\begin{array}{l}\text { Ortalama (Min-Max) } \\
78 \pm 1.8 \mathrm{mmHg}(53-106) \\
97 \pm 3.4 \mathrm{atım} / \mathrm{dk}(63-169) \\
29.3 \pm 1.2 / \mathrm{dk}(12-42) \\
37.5 \pm 0.1^{\circ} \mathrm{C}(36.2-38.9)\end{array}$ \\
\hline $\begin{array}{l}\text { Laboratuvar değeri } \\
\text { Beyaz küre } \\
\text { \% Nötrofil oranı } \\
\text { ALT } \\
\text { AST } \\
\text { Üre } \\
\text { Kreatinin } \\
\text { CRP } \\
\text { Prokalsitonin } \\
\mathrm{PaO}_{2} \\
\mathrm{PaCO}_{2} \\
\text { Satürasyon- }_{2}\end{array}$ & $\begin{array}{l}\text { Ortalama (Min-Max) } \\
10.7 \pm 0.6 \times 10^{3}(1.5-20.5) \\
78.7 \pm 1.5(50-94) \\
25.1 \pm 3.2(3.6-99) \\
34.1 \pm 4.7(8.7-183) \\
73.8 \pm 7.5(17-146) \\
1.4 \pm 0.1(0.2-4.9) \\
10.1 \pm 1.6(0.2-47.5) \\
8.8 \pm 3.3(0.1-100) \\
80.9 \pm 3.9(39.2-181) \\
38.2 \pm 1.7(20.8-84.1) \\
91.9 \pm 0.8(73-98.3)\end{array}$ \\
\hline $\begin{array}{l}\text { Balgam kültürü }(\mathbf{n}=38) \\
\text { Üreme yok } \\
\text { Üreyen mikroorganizma } \\
\text { S. pneumonia } \\
\text { M. catarhalis } \\
\text { Gram-negatif basil }\end{array}$ & $\begin{array}{l}\text { Sayı (\%) } \\
33(86.8) \\
1 \\
1 \\
2\end{array}$ \\
\hline $\begin{array}{l}\text { Radyolojik tutulum }(\mathrm{n}=47) \\
\text { Unilateral unilober } \\
\text { Unilateral multilober } \\
\text { Bilateral multilobar }\end{array}$ & $\begin{array}{l}\text { Sayı (\%) } \\
17(36) \\
8(17) \\
22(47)\end{array}$ \\
\hline
\end{tabular}

komorbid hastalıklarının mevcut olduğu görüldü. Tüm hastalarda bir veya birden cok komorbid hastallk mevcuttu.

Hastaların \%80.9'u ( $n=38$ ) sigara içme alıșkanlıklarının devam ettiğini, \%19.1'i ise hayatlarının hiçbir döneminde sigara içmediğini belirtti. Hastalarının hiçbirinin sigarayı bırakma öyküsü yoktu.

Hastaların akciğer radyogramı tutulumlarına bakıldığında; \%36'sında ( $n=17)$ unilateral unilober tutulum, \%17'sinde $(n=8)$ unilateral multilober tutulum, \%47'sinde $(\mathrm{n}=22)$ bilateral multilober tutulum görülmüștür. Ayrıca hastaların \%34'ünde radyogramda plevral sivı tespit edilmiștir. Akciğer radyolojisi normal tespit edilen hiçbir hasta yoktu (Tablo 1).

Hastaların \%15'i ( $\mathrm{n}=7$ ) ayaktan tedavi görmüstür. Yatan hastaların yattığı birimler değerlendirildiŏinde; \%13' $\mathrm{u}(\mathrm{n}=5)$ ic hastalıkları servisine,
$\% 25$ ' $\quad(n=10)$ infeksiyon hastalıkları ve klinik mikrobiyoloji servisine, \%17'si ( $\mathrm{n}=7)$ göğüs hastalıkları servisine ve $\% 45$ 'i $(n=18)$ yoğun bakım ünitesine yatırılarak tedavi edilmiștir.

Hastaların CURB-65 skorları incelendiğinde; \%15'inin ( $\mathrm{n}=7)$ skorları 2'den küçük bulunmus olup, bu hastalar rehber önerileri doğrultusunda ayaktan tedavi edilmișlerdir. Yatarak tedavi alan tüm hastalarda ise CURB-65 skoru 2 ve üzerinde hesaplanmıștır.

Hastaların kültür durumları ve sonucları incelendiğinde; 38 hastanın balgam kültürü için örnek verebildiği ve bu kültür sonuçlarında; bir hastada $S$. pneumoniae, bir hastada $M$. catarrhalis, iki hastada gram-negatif bakteri (iki hastada da Pseudomonas aeruginosa üremesi olmuștur) ve dört hastada kar1șk cins mikroorganizma üremesinin olduğu görüldü. Hastaların 33'ünde balgam kültüründe üreme saptanmadığı (\%86.8) görülmüsțür (Tablo 1). 
Hastaların kan kültürü sonuçları incelendiğinde; iki hastanın kan kültürlerinde gram-negatif bakteri (iki hastada da $P$. aeruginosa üremesi olmuștur) ve bes hastanın kan kültüründe koagülaz negatif stafilokokların ürediği görülmüștür.

Hastaların altısında idrar pnömokok antijeni pozitif olarak bulunmuștur. $\mathrm{Bu}$ hastaların balgam kültür sonuçlarına bakıldığında sadece bir hastanın balgamında $S$. pneumoniae üremesi olduğu, diğer hastaların balgam kültürlerinde üreme olmadığı görülmüștür. $\mathrm{Bu}$ altı hastanın kan kültürlerinde ise mikroorganizma üremesi olmamıștır. Antijen pozitif tüm hastaların CURB 65 skorunun 2'nin üstünde olduğu görülmüștür.

Hastanemize çalıșma süresince bașvuran tüm hastalar içinde, TKP nokta prevalansı $\% 0.31$ ve S. pneumoniae'ye bağlı pnömoni oranının \%12.7 $(n=6)$ olduğu görülmüștür. Balgam kültürü ile bir hastaya (\%2.1), idrar pnömokok antijen testi ile altı hastaya (\%12.7) pnömokok pnömonisi tanısı konulabilmiștir.

\section{TARTIȘMA}

TKP, hafif bir alt solunum yolu infeksiyonundan ciddi mortalite ve morbiditeye neden olacak siddette spektrumu olan bir halk sağlığ sorunudur. Hastalık sıklikla akut bir tablo seklinde gelismekte ve ampirik tedavi yaklașımı gerektirmektedir. Ampirik tedavi yaklașımında klinik ve radyolojik bulgular önemli olmaktadır [6,13-15].

TKP, yașla birlikte artıs göstermekle birlikte özellikle 65 yaşından büyük olmak hastalık gelișimi için önemli bir risk faktörüdür ${ }^{[6,15]}$.

Calıșmamızda hastalarda mevcut komorbid faktörler literatürde tanımlananlar ile uyumlu bulunmuștur ${ }^{[17-19]}$. Tanı ve tedavisi yapılan hastaların tamaminda bir ya da birden cok komorbid hastalı mevcut olması ise yas ortalamasının benzer calıșmalara göre yüksekliğine bağlanmıștır.

TKP'li hastaların radyolojik görüntülemesinde en sk lober tutulum seklinde infiltrasyonlar görülmekte olup, \%82-89 arasında saptanmaktadır ${ }^{[20]}$. Calıșmamızda en sik bilateral multilober tutulum olduğu görülmüștür.

TKP vakalarında ceșitli skorlama sistemleri dünyada sı olarak kullanılmakta olup, CURB, PSI ve CURB-65 bunlardan bazılarıdır. Calıșmamızda yatan hastalarda CURB-65 puanı tüm hastalarda 2-5 arasında saptanmıstır. Hastaneye yatırılarak izlenilen tüm hastaların CURB-65 skorlarının 2 ve üzerinde olması literatür ve tanı, tedavi rehberlerinin önerileri ile uyumlu bulunmuștur ${ }^{[15,21,22]}$. İdrar pnömokok antijen testi pozitif çkan tüm hastalarda CURB 65 skoru $>2$ olduğu görülmüs ve klinik tablonun ağır olması nedeniyle bu hastaların bakteriyemik seyretmesi nedeniyle testin tanı değerinin daha iyi olduğunu düșündürmüștür. Ancak bu hastaların hiçbirinde de kan kültüründe bakteri üretilememiș olmasının, idrar antijen testinin bașarısına ișaret ettiğini düșünmekteyiz.

Calıșmamızda TKP'nin hastanemizdeki nokta prevalansı, bu pnömoniler içinde pnömokok pnömonisinin oranı, idrar antijen testinin konvansiyonel yöntemlere ek olarak kullanılmasının etken saptanma oranına olan etkisi araștırılmıs olup, TKP tanısı olan kırk yedi hastanın altısında (\%12.7) idrar pnömokok antijen testi pozitif saptanmıs, bu hastaların sadece birinin (\%2.1) balgam kültüründe pnömokok üremesi olmuștur. $\mathrm{Bu}$ hastaların hiçbirinin kan kültüründe pnömokok üremesi saptanmamıstır. Literatürde, idrar pnömokok antijen testi ile ilgili calıșmalar kısıtl sayıda olup; Devin ve arkadasslarının yaptıkları genis çaplı bir çalıșmada, hastaların idrar örneklerinde pnömokok antijeni taranmıs ve calıșmamızla benzer olarak \%12'sinde pozitif saptanmıștır [16]

Yetiskinlerde TKP tanı ve tedavi rehberleri, TKP tanısında idrar pnömokok antijen testinin tedaviye yanıt alınamayan, yoğun bakım ünitesinde takip edilmekte olan, pnömokoksik pnömoni için risk faktörleri mevcut hastalar için yapılmasın1 önermektedir ${ }^{[13-15]}$. Testin duyarlllığı \%70-80, özgülllüğü \%80-100 olup, pozitif prediktif değeri $\% 68$, negatif prediktif değeri $\% 92$ olarak belirtilmiștir.

Testin hızlı sonuc vermesi, antibiyotik kullanımından etkilenmemesi gibi avantajları mevcut olup, bakteremik olmayan pnömonilerde duyarl1llk ve özgülliuğünün düsüuk olması ve antibiyotik duyarlllı testlerinin yapilmasına imkan vermeyiși kullanımdaki olumsuz yönleridir. Calıșmamızda, konvansiyonel kültür yöntemleri ile birlikte kullanıldığında, S. pneumoniae'nin tanı oranını artırdığı sonucu bulunmuștur. 
Sonuc olarak idrar pnömokok antijen testinin pnömokok pnömonisi için risk faktörleri mevcut TKP hastalarında; özellikle balgam örneği veremeyen hasta grubu için geleneksel tanı yöntemlerine ek bir tanı metodu olarak kullanılmasının, etkenin tanımlanma sansını artırabileceğini ve bu konu ile ilgili daha cok calıșma yapılmasının literatüre katkı sağlayabileceğini düșünmekteyiz.

\section{TEȘEKKÜR}

Calıșma; cok merkezli bir çalıșmanın Canakkale ayağını olușturmakta olup, etik kurul onayı Gazi Üniversitesi Tıp Fakültesi Bilimsel Araștırmalar Etik Kurulu'ndan alınmıștır. CCalıșmamıza verdiği destekten dolayı proje bas koordinatörü Prof. Dr. Esin Senol'a teșekkür ederiz.

\section{ETIK KURUL ONAYI}

Çalıșma için Gazi Üniversitesi Tıp Fakültesi Bilimsel Araștırmalar Etik Kurulundan alındı (Karar no: E3831 Tarih: 09.01.2017).

\section{ÇIKAR ÇATIȘMASI}

Yazarlar bu makale ile ilgili herhangi bir çkar catıșması bildirmemișlerdir.

\section{YAZAR KATKISI}

Anafikir/Planlama: AȘ, RD

Analiz/Yorum: AS, RD

Veri Sağlama: RD

Yazım: AS

Gözden Geçirme ve Düzeltme: AȘ, RD

Onaylama: AS

\section{KAYNAKLAR}

1. Broulette J, Yu H, Pyenson B, Iwasaki K, Sato R. The incidence rate and economic burden of community-acquired pneumoniae in a working age population. Am Healt Drug Benefits 2013;6(8):494-503.

2. Ramirez JA, Wiemken TL, Peyrani P, Arnold FW, Kelley R, Mattingly WA et all. Adults hospitalized with pneumonia in the United States: incidence, epidemiology, and mortality. Clin Infect Dis 2017;65(11):1806.

3. Almiral J, Bolibar I, Vidal J, Sauca G, Coll P, Niklasson B, et al. Epidemiology of community acquired pneumonia in adults: a population-based study. Eur Respir J 2000;15(4):757-63.

4. Heron M, Hoyert DL, Murphy SL, Xu J, Kochanek KD, Tejada-Vera B. Deaths: Final data for 2006. Natl Vital Stat Rep 2009;57(14):1-134.
5. UpToDate. Ramirez JA. Overview of community-acquired pneumonia in adults. Available from: www.uptodate.com. Accessed date: 11 November 2019.

6. Metlay JP, Waterer GW, Long AC, Anzueto A, Brozek J, Crothers $K$, et al. Diagnosis and treatment of adults with community-acquired pneumonia. An official clinical practice guideline of the American Thoracic Society and Infectious Diseases Society of America. Am J Respir Crit Care Med 2019;200(7):e45-e67.

7. Marcos MA, Jimenez de Anta MT, de la Bellacasa JP, Gonzales J, Martinez E, Garcia E, et al. Rapid urinary antigen tests for diagnosis of pneumococcal community acquired in adults. Eur Respir J 2003;21(2):209-14.

8. Ehara N, Fukushima K, Kakeya H, Mukae H, Akamatsu S, Kageyama A, et al. A novel method for rapid detection of Streptococcus pneumoniae antigen in sputum and its application in adult respiratory tract infections. I Med Microbiol 2008;57(7):820-6.

9. Toplum kökenli pnömoniler. In: Willke Topçu A, Söyletir $G$, Doğanay M. (eds). 4. Baskı. Infeksiyon Hastalıkları ve Mikrobiyolojisi. Istanbul; Nobel Tıp Kitabevleri, 2017: 771-93.

10. West DM, McCauley LM, Sorensen JS, Jephson AR, Dean NC. Pneumococcal urinary antigen test use in diagnosis and treatment of pneumonia in seven Utah hospitals. ERJ Open Res 2016;2(4):00011-2016.

11. Mandell LA, Wunderink RG, Anzueto A, Bartlett JG, Campbell GD, Dean NC, et al. Infectious Diseases Society of America/American Thoracic Society consensus guidelines on the management of community-acquired pneumonia in adults. Clin Infect Dis 2007;44(2):27.

12. Roson B, Fernandez-Sabe N, Carratala J. Contribution of a urinary antigen assay (Binax NOW) to early diagnosis of pneumococcal pneumonia. Clin Infect Dis 2004;38(2):2226.

13. Ehara N, Fukushima K, Kakeya H, Mukae H, Akamatsu S, Kageyama A, et al. A novel method for rapid detection of Streptococcus pneumoniae antigen in sputum and its application in adult respiratory tract infections. I Med Microbiol 2008;57(7):820-6.

14. Kawana A, Furihata K, Yamauchi $Y$, Kawaishi $M$, Kobayashi $N$, Kudo K. Comparison of five guidelines of community-acquired pneumonia. Nihon Kokyuki Gakkai Zasshi 2001;39(11):829-36.

15. Torres A, Peetermans WE, Viegi G, Blasi F. Risk factors for community-acquired pneumonia in adults in Europe: a literature review. Thorax 2013;68(11):1057.

16. Devin MW, Lindsay MM, Jeffrey SS. Pneumococcal urinary antigen test use in diagnosis and treatment of pneumonia in seven Utah hospitals. ERJ Open Res 2016;2:000112016.

17. Ruiz M, Ewing S, Torres A, Arancibia F, Marco F, Mensa J, et al. Severe community-acquired pneumonia: risk factors and follow-up epidemiology. Am / Respir Crit Care Med 1999;160(3):923-39. 
18. Özlü T, Karahan H, Bülbül Y. Servise yatırılarak tedavi edilen ve risk faktörü taşıyan erişkin toplum kökenli pnömoni (TKP) hastalarında Moksifloksasin monoterapisi ile Seftriakson+Klaritromisin kombinasyonunun, etkinlik ve güvenilirliğinin karşılaştırılması. Solunum 2011;13(1):9-13.

19. Çilli A, Özdemir $T$, Öğüş C, Kara A. Ciddi toplum kökenli pnömonide etyoloji ve prognostik faktörler. Tuberk Toraks 2001;49(3):312-6.

20. Sopena N, Sabria-Leal M, Pedro-Botet ML, Padilla E, Dominguez J, Morera J, et al. Comparative study of the clinical presentation of Legionella pneumophila and other community-acquired pneumonias. Chest 1998;113(5):1195-200.

21. Woodhead M, Blasi F, Ewig S, Garau J, Huchon G, leven $M$, et al; Joint Taskforce of the European Respiratory Society and European Society for Clinical Microbiology and Infectious Diseases. Guidelines for the management of adult lower respiratory tract infections. Clin Microbiol Infect 2011;17(6):1-59.
22. National Institute for Health and Care Excellence (NICE). Pneumonia in adults: diagnosis and management. Clinical Guideline 2014;191:1-27.

\section{Yazıșma Adresi/Address for Correspondence}

Prof. Dr. Alper ȘENER

Canakkale 18 Mart Üniversitesi Tıp Fakültesi,

İnfeksiyon Hastalıkları ve

Klinik Mikrobiyoloji Anabilim Dalı,

Canakkale-Türkiye

E-posta: dr.alpersener@gmail.com 